\title{
Katarzyna Wojewoda-Buraczyńska
}

Siedlce University of Natural Sciences and Humanities (Poland)

\section{Social Policy within the Framework of Public Self-Governance - Selected Topics}

\begin{abstract}
The article herein discusses selected issues of the effectiveness of public governance model at the Province level of self-governance in regard to providing support services to persons with disabilities. Described herein are tasks for carrying out the policy of social inclusion of persons with disabilities that are the responsibility of the Province self-governance. Also described is the method for carrying out the said tasks and the most frequently used model of public governance. Discussed also are the critical challenges and flaws of the said model of public governance. Presented also are some suggestions for changes in regard to the discussed areas. The aim of the article is to analyze province social policy toward people with disabilities. The article also attempts to evaluate the methods used to implement it. The article is based on the analysis of legal acts regarding the social inclusion policy of persons with disabilities at the level of the province, with particular emphasis on the content of province programs on equal opportunities for people with disabilities and counteracting social exclusion and assistance in the implementation of tasks for the employment of disabled people. When writing an article, the dogmatic method was used in the analytical approach. The article proposes a thesis that the collaborative governance model used to implement the social inclusion policy of disabled people at the province level does not ensure sufficient control over the efficiency of using public funds, and thus does not guarantee the effective implementation of public tasks by non-public entities.
\end{abstract}

Keywords: persons with disabilities; social inclusion; interactive management; province level social policy; province local development policy

\section{General Comments}

The Constitution of the Republic of Poland is charged with care for persons with disabilities. The Constitution guarantees the persons with disabilities particular (special) rights regarding health and medical care. Moreover, under the Constitution, persons with disabilities are guaranteed state provided assistance regarding their welfare, employment and social participation (Konstytucja RP, 1997; Banaszek, 2009; Skrzydło, 2000). The mentioned support is to 
be provided as set for in the Constitution. In addition to public assistance provided by the state, there are other public entities that are obligated to support to persons with disabilities. Among these are the Province self-governance bodies. Most often, said entities try to, under the pretense of activization of the local communities, push these burdens of caring for people with disabilities onto private (mostly third sector) local entities. Although, commissioning and outsourcing services for persons with disabilities to third parties in the private sector is allowed under the laws and regulations pertaining to Province self-governance, it would be warranted to evaluate whether the scope of such "passing on the responsibility" should not be more limited.

\section{Province Responsibilities Regarding Services for Persons with Disabilities}

The legal acts and statutes, which determine the structures of bodies of local-governance, mandate these bodies to adopt and carry out duties for the welfare of the citizens of their local communities, including support services for persons with disabilities. According to the Act on Province Government the following are the tasks to be carried out by the province self-governance (the Act on Province Government, 1988):

- Preserving and promoting the Polish heritage and culture, forging and preserving the national awareness and identity and civic attitude, upholding the values of the country of Poland as a whole and of one's local community;

- Awakening and forging economic activity;

- Promoting and strengthening the level of competitiveness and innovation in the economic organization of the province;

- Maintaining and preserving the values of the natural surroundings and cultural heritage for the benefit of future generations;

- Forming and preserving the spatial order in term of environmental management and planning.

The listed aims shall be adhered to when planning the local Province strategy which shall be then implemented under the policy for the development of the Province. The policy shall be based on the following premises:

- Development of conditions conducive to economic development inclusive of labor market conditions;

- Sustaining and expanding social, economic and technological infrastructure for the Province;

- Securing and effectively link public and private partners for the purpose of effective implementation of public tasks;

- Carrying out and supporting activities directed at improving the level of education of the Province's citizenry;

- Rational usage and management of the environmental resources and management of the environment consistent with the principles of sustainable development; 
- Support for education and cooperation between education and economy along with support for technological innovations and advancement;

- Promoting cultural advancement; protecting and ensuring the rational usage of cultural heritage;

- Promotion of the assets and the potential of the province;

- Support for and carrying out activities directed at social integration and counteracting social exclusion (Act on Province Government, 1988).

The mentioned Act on Province Government mandates the Province self-government to support and carry out activities directed at promoting and increasing social integration while counteracting social exclusion. In the opinion of the author, the said mandate can be effectively discharged only if all and any activities will be evaluated as being designed for and benefiting all citizens, including persons with disabilities.

In addition, the Rehabilitation Act mandates the Province Self-government to carry out activities designed to support and aid persons with disabilities (The Rehabilitation Act, August 27,1997). The Act mandates the Province Self-government to:

- Develop and carry out the Province program for equal treatment and leveling the chances for persons with disabilities and counteracting social exclusion by supporting employment of persons with disabilities;

- Gather, analyze and present the Plenipotentiary for Persons with Disabilities with information regarding the realization of the said mandate;

- Subsidize the construction works for erecting facilities dedicated to providing rehabilitation services for persons with disabilities, with the exclusion of the costs of demolishing such objects;

- Subsidize the costs of developing and carrying out employment for persons with disabilities;

- Cooperate with administrative entities of the State, county and communes in regard to carrying out the said mandate;

- To give an opinion in regard to requests to enter centers offering group rehabilitation services to persons with disability into the Province registry (the Rehabilitation Act, 1997).

The Province Self-government is supported in carrying out of the listed activities by the Province Social Council for Persons with Disabilities. The Rehabilitation Act mandates the council to encourage and instigate undertaking aiming at social and vocational integration of persons with disabilities, giving an opinion and assessing the outcomes of the Province programs for carrying out activities in support of persons with disabilities and giving an opinion regarding the assumed outcomes presented in the drafts of resolutions and programs for persons with disabilities to be adopted by Province Assembly (the Rehabilitation Act, 1997).

In addition to its own budgetary resources allocated for the support of persons with disabilities, the Province Self-government can apply for and receive subsidiary funding 
from the State Fund for the Rehabilitation for Persons with Disabilities (PEFRON). These funds can be used to:

- Subsidize construction of facilities designed and designated for rehabilitation of persons with disabilities;

- Subsidize the costs of development and operation of places of employment and vocational activity for persons with disabilities;

- Commissioning and outsourcing services for persons with disabilities to NGOs (Decree of the Council of Ministers', 2003).

\section{Public Governance and Support for Persons with Disabilities}

There is no unified definition for the term "public governance". It can be defined in terms of activities or functions or in terms of process. The functional management can be understood as structuring of an organization into dedicated units or organizational elements based on the allocated and/or designated tasks and by the type of activity of tasks performed. The process management can be understood as set of repetitious, organized in accordance of an decided upon scheme activities aimed at achieving the agreed upon objective(s). Process management involves, planning, organizing, allocating and a proper utilization of an organization's resources and assets, and adequate management of human resources, with a focus on achieving the organizational goals in the most effective way. In general, management is understood as an activity directed as achieving a goal or a set of goals with a set group of people (subject of management). Management occurs in an organization, which has a management body that possesses the power or otherwise owns the management process and the right of decision over the management of the resources and assets of the organization (Marks-Krzyszkowska, 2016; Bogacz-Wojtanowska, 2013; Bogacz-Wojtanowska 2007).

Defining public governance is somewhat more difficult. The object of such management is generally defined as the public sector or the public matters and interests. The subject is usually comprised of numerous independent systems and institutions (Szumowski, 2014; Kożuch, 2015; Kożuch, 2003; Kożuch, 1997).

The State constitutes a very particular management subject. As such, it possesses attributes of power and makes decisions for and on the behalf of its citizens. Every state possesses a defined set of norm and rules defining the principles of its political principles and structure and the workings of its administration. It differs, even so, in particular states in references to the degree of participation by the citizens in the process of decision making in regard to key state issues; the means of influencing decision makers; the partition of powers and the manner in which the powers are carried out. So, the so called "public sector" is not confined only to the State and its government. It means that there are and can be other entities, both from the private and the NGO sectors that can carry out public tasks. Yet, without a doubt, the leadership in the process of creation of public policy at the national level rests with 
the State and at the local level with the local self-governances appropriate to the scope of responsibilities and the tier of executive force of decision rested with them.

There are various different theoretical models of public governance. Still, experts in this doctrine are generally in accord that it is difficult to ascertain any of the said models in operation in its pure form. Most frequently, observed can be so called "mixed" models with the eventual dominating presence of a particular model of public governance. Currently dominates the so called "interactive" or "participatory" model of public governance. It requires developing a management structure where some organizational competencies and/or powers are shared and executed jointly while the overall autonomy of the individual participating entities is preserved. In that regard it establishes a new quality of public governance based on cooperation, trust and mutual interests. According to some experts, this positive trend should be expanded upon to include cooperation with entities external to public governance bodies with the aim at decentralization while applying proper techniques of negotiations, discussion and persuasion (Sześciło, 2014; Marks-Krzyszkowska, 2016; Peter-Bombik, 2018; Peter-Bombik, 2017).

Nevertheless, the interactive style of public governance, however beneficial, is not faultless. Among its most often cited shortcomings are:

- Sort of an idealistic character;

- The relatively high risk of becoming corrupted; and

- Use of this form of public governance as a panacea for the helplessness of some of the entities of public-governance in carrying out their mandate (Marks-Krzyszkowska, 2016; Peter-Bombik, Szczudlińska-Kanoś, 2016; Marszałek-Kawa, 2016; PeterBombik, Szczudlińska-Kanoś, 2015).

However, based on the analysis of the activities carried out by public governance entities it can be observed than a majority of tasks that are the charge of the Province self-governance body is carried out indirectly via the interactive management mode.

\section{New Approach in the Policy of Social Inclusion of People with Disabilities at the Province Level}

The policy of the Province governance relative to providing support for persons with developmental disabilities is implemented via the Province's programs aimed at leveling the chances, preventing and counteraction social exclusion and assisting other entities in carrying out their programs and services for persons with disabilities. These programs are developed individually by each of the Province, are time limited and set the policy direction for each Province in terms of services and support to be provided for persons with disabilities. Generally, these programs have a 5-6 years lifespan (Annex to Resolution No. XLIV/812/14, Annex to Resolution No. XIV/253/12, Annex to Resolution No. XLI-795-14, Annex to Resolution No. XLIV/812/14, Annex to Resolution No. XLVI/542/14, Annex to Resolution No. XLII/746/14, Annex to Resolution No. XLV/701/2014, Annex to Resolution 
No. 1546/2015, Annex to Resolution No.45/1376/12, Annex to Resolution No.395/14, Annex to Resolution No. 821/371/14, Annex to Resolution No. 82/167/V/2017, Annex to Resolution No. 2079/394/17).

Despite significant diversity among different Provinces regarding level of affluence, the size of the population, level of industrialization, and economic prosperity the programs for assistance for persons with disabilities are not very different from each other. Each consists of at least two main parts. The first identifies key problems and challenges encountered by persons with disabilities. The second lays out the solutions to the identified problem and challenges. Significant similarities are quite apparent, particularly regarding the challenges and difficulties in counteracting social exclusion and the catalogues of the aims and methods of achieving these aims. Among the most often listed barrier to full social participation and integration are:

- Limited access to employment;

- Architectural, communication, urbanistic, and technological barriers;

- Limited access to rehabilitation;

- Limited access to information;

- Fragmented and scattered support system; and

- Limited access to education.

Despite the efforts undertaken by the Province Self-governance aimed at the elimination of the said barriers it is still quite apparent that some areas re in a drastic need for quick changes. Although, some efforts to that end are being carried out they are also not flawless. Among the most frequently listed flaws are:

- Low level of awareness of persons with disabilities regarding their rights;

- Low level of education of person with disabilities;

- Low degree of vocational and social activity of persons with disabilities, particularly among those living in agricultural areas and small villages;

- Low level of key social and vocational competencies and skills of persons with disabilities; and

- Education poorly aligned with the needs and abilities of persons with disabilities;

- Education of persons with disabilities not responsive to the realness of the labor market;

- Lack of effective employment policy for persons with disabilities;

- Activities aimed at supporting persons with disability, lack cohesiveness;

- Difficult economic conditions of persons with disabilities;

- Low level of social awareness regarding persons with disabilities;

- Territorially differentiated level of human resources;

- Activities aimed at supporting persons with disabilities are scarce and scattered;

- Low level of financial participation by the Province Self-governance regarding support of persons with disabilities; 
- Inadequate, in regard to the needs, level of funding for vocational and social rehabilitation of persons with disabilities;

- Insufficient efforts in seeking the EU funding by entities aiming at supporting persons with disabilities; and

- Unstable and incohesive law.

While the listed barriers to social inclusion are considered to be the weakest points within the system of support for persons with disabilities it is probable that a large portion of the barriers will not be removed. At the same time, it is difficult to unambiguously identify why.

The limited level of funding is cited among the challenges in carrying out programs for supporting persons with disabilities. At the same time, however, cited is the inefficiency in seeking the EU funds. It implies that funding is available, but the methods of procuring and securing the funding are rather inadequate. This is frequently cited as a serious threat to carrying out support programs for persons with disabilities. There are also other factors that should be evaluated and addressed. Perhaps, it would be warranted to change the budget allocations of funds. For certain, a systemic and systematic approach, based on allocating funds corresponding with and adequate to the needs, is needed to rationalize and streamline the allocation of funds at the phase of planning of the budget. Too much fragmentation, which is almost written into the idea of cooperative management of public affairs, makes coordination of such efforts rather difficult.

In general, the goals of the programs for the support of persons with disabilities include:

- Education (directed not only at persons with disabilities, but also the general population, particularly regarding legal mandates and institutional solutions; and addressing the social standing of persons with handicaps within the community at large);

- Vocational activization of persons with disabilities;

- Social and medical rehabilitation (including increasing the number of public facilities, eliminating architectural and communication barriers, and making it easier to access medical and other support services);

- Improving integration of entities providing support services to persons with disabilities (particularly regarding development of data basis and platforms for easy access and exchange of information).

\section{Conclusions}

Based on analysis of data gathered regarding the programs from leveling chances, counteracting social exclusion and promoting the employment of persons with disabilities it can be noticed that in general the Province Self-governances directly execute two types of tasks.

The first category could be defined as an educationally-informative. However, in reality the execution of these programs is commissioned from and outsourced to external third 
parties thus reducing the role of the Province Self-governance to funding these activities. Among the most frequently funded activities within this category are picnics and other outdoor activities, organization and operation of information kiosks and running information media campaigns.

The second category of tasks revolves around removing and eliminating architectural barriers to access facilities constructed with funds that are within the jurisdiction of the Province Self-Governance. It is, however, worth noticing that the Province Self-governance is also mandated under the provisions of the Building Code, to carry out these activities.

All remaining tasks regarding support for persons with disabilities are commissioned by the Province Self-governance from independent, non-public third-party entities, and, as the results of analysis of these programs prove, the effects is rather low in terms of efficiency. Thereby, when desiring to develop an effective program for support of persons with disabilities the current system must be modified. It appears that foregoing the current model of public governance is both unwarranted and impossible. It seems, however, that well warranted would be a creation of a coordinated, national level, inclusive of all Province Self-governances, system for exchange of information containing data regarding all forms of support, entities providing these services and the entitled beneficiaries. An access to such systemized information would, in the author's opinion, significantly increase accessibility of services and allow for better identification of underserved areas. It would present the first step to improving the coordination of services for persons with disabilities. It would also greatly contribute to improving the transparency and openness regarding funding and safeguard against possible corruption.

To further increase the effectiveness of the Province Self-governance it would be warranted to elevate and strengthen the level of direct engagement by these bodies into carrying out the policy for social inclusion. In addition to creating a database, the Province Selfgovernances should verify the effectiveness of the commissioned and outsourced tasks in a true and not an illusory manner. The false veneer like character of activities being carried out can be easily observed, particularly at the level of the Province Self-governance, when analyzing the contents of the of the Province Self-governance programs for leveling chances, promoting employment and counteracting social exclusion of persons with disabilities. Equally, as it was noted earlier, the sole difference between these programs for all Provinces comes from different demographics and other statistical data for each of the Province and that's where the differences end. It looks every bit if all the programs were produced using the cookie cutter approach with empty places left for filling in the regional, economic or demographic information. information. Some of that phenomenon can be attributed to the fact that some of the programs for persons with disabilities are the same at the national level. It, is warranted, however, in the opinion of the author, to reflect and account for regional differences at the level of individual Provinces in a real manner.

The universal nature of these programs creates another flaw. Although, there are inherent difficulties in providing certain services that arise from the very nature of the Province gov- 
ernance, these should not be further intensified by the undistinctive nature of the programs and more so multiplied by the "fill in the form" type of bureaucratic pseudo-language, which in reality does not allow for creativity and latitude in defining the outcomes thus negatively affecting the program effectiveness.

Moreover, particular elements of the regional policy for supporting persons with disabilities should be reflected in the programs developed at the Province level in a way that ensures assessment of their effectiveness. It would be possible to achieve that objective, even if the activities would be defined in general terms, provided that adequate standards and indicators would be put in place to evaluate program effectiveness.

Practice proves that it is the third parties, most often private entities, that step forward with initiatives for concrete programs aimed at encouraging social inclusion. In such cases the role of the Province Self-governance is reduced to issuing a formal assessment of the proposed initiative. The goals of the regional policy for social inclusions are broadly and generally described which affords the Provinces a significant freedom in disbursing funds allocated for this sphere. This, in turn, is conducive to waste or misuse of funds and introduces opportunities for corruption. It seems that a much safer solution would be a direct involvement in designing the programs by the Province Self-governance, subject to prior identification and systemizing of the underserved areas, and for the third-party service providers to apply via public tenders for the permission to carry out preapproved program or programs.

Although, it appears that the synergistic model of public governance constitutes the best modality of management in regard to the policy of social inclusion, yet even so, the Province Self-governances shall not forget that passing on some of their competencies onto the third parties does not liberate them from responsibility for the consequences. Finally, commissioning and outsourcing of public tasks to third private sector parties shall not be the outcome of the Self-governance helplessness, but to the contrary the result of a carefully chosen model of public governance.

Based on the analyzed source material, it should be stated that the thesis that the collaboration governance model used to implement the social inclusion policy of disabled people at the province level does not ensure sufficient control over the effectiveness of using public funds, and thus does not guarantee effective implementation of public tasks by non - public entities has been proved. 


\section{References}

\section{Acts of Law}

Konstytucja Rzeczypospolitej Polskiej z dnia 2 kwietnia 1997 roku (Dz. U. nr 78, poz. 483, ze zm.).

Ustawa z dnia 27 sierpnia 1997 roku o rehabilitacji zawodowej i społecznej oraz zatrudnianiu osób niepełnosprawnych (t.j. Dz. U. z 2018r., poz. 511, ze zm.).

Ustawa z dnia 5 czerwca 1998 roku o samorządzie województwa (t.j. Dz. U. z 2018, poz. 913, ze zm.).

Rozporządzenie Rady Ministrów z dnia 13 maja 2003 roku w sprawie algorytmu przekazywania środków Państwowego Funduszu Rehabilitacji Osób Niepełnosprawnych samorządom wojewódzkim i powiatowym (Dz. U. nr 88, poz. 808).

Załącznik do uchwały nr XIX/317/08 Sejmiku Województwa Podkarpackiego z dnia 25 lutego 2008 roku w sprawie uchwalenia Wojewódzkiego Programu Na Rzecz Wyrównywania Szans Osób Niepełnosprawnych i Przeciwdziałania Ich Wykluczeniu Społecznemu na lata 2008-2020.

Załącznik do uchwały Nr XIV/253/12 Sejmiku Województwa Warmińsko-Mazurskiego z dnia 21 lutego 2012 roku w sprawie przyjęcia zaktualizowanej Strategii polityki społecznej województwa warmińskomazurskiego do 2020 roku.

Załącznik do Uchwały nr XLI-795-14 Sejmiku Województwa Wielkopolskiego z dnia 27 stycznia 2014 roku Program dotyczacy wyrównywania szans osób niepełnosprawnych i przeciwdziałania ich wykluczeniu społecznemu oraz pomocy w realizacji zadań na rzecz zatrudniania osób niepelnosprawnych $w$ Województwie Wielkopolskim na lata 2014-2020.

Załącznik do uchwały Nr XLIV/812/14 Sejmiku Województwa Łódzkiego z dnia 10 lutego 2014 roku w sprawie: przyjęcia Wojewódzkiego Programu Wyrównywania Szans Osób Niepełnosprawnych i Przeciwdziałania Wykluczeniu Społecznemu oraz Pomocy w Zatrudnieniu Osób Niepetnosprawnych na lata 2014-2020.

Załącznik do uchwały nr XLVI/542/14 Sejmiku Województwa Lubuskiego z dnia 24 marca 2014 roku Strategia Polityki Społecznej Województwa Lubelskiego na lata 2014-2020.

Załącznik do uchwały Nr XLII//746/14 Sejmiku Województwa Świętokrzyskiego z dnia 28 kwietnia 2014 roku Wojewódzki program wyrównywania szans osób niepełnosprawnych i przeciwdziałania ich wykluczeniu społecznemu oraz pomocy $w$ realizacji zadań na rzecz zatrudniania osób niepetnosprawnych na lata 2014-2020.

Załącznik do uchwały nr XLV/701/2014 Sejmiku Województwa Lubelskiego z dnia 26 maja 2014 roku Program wyrównywania szans osób niepełnosprawnych i przeciwdziałania ich wykluczeniu społecznemu oraz pomocy w realizacji zadań na rzecz zatrudniania osób niepetnosprawnych na lata 2014-2020.

Załącznik do uchwały Nr 1546/2015 z dnia 28 grudnia 2015 Sejmiku Województwa Opolskiego w sprawie przyjęcia Wojewódzkiej Strategii w Zakresie Polityki Społecznej na lata 2016-2025.

Załącznik do uchwały Nr 45/1376 /12 Zarządu Województwa Kujawsko-Pomorskiego z dnia 7 listopada 2012 roku Równe szanse. Program działania na rzecz osób niepełnosprawnych do 2020 roku.

Załącznik do uchwały Zarządu Województwa Małopolskiego z dnia 15 kwietnia 2014 roku nr 395/14 Wojewódzki program dotyczący wyrównywania szans osób niepełnosprawnych i przeciwdziałania ich wykluczeniu społecznemu oraz pomocy w realizacji zadań na rzecz zatrudniania osób niepełnosprawnych w Województwie Małopolskim na lata 2014-2020.

Załącznik Nr 1 do Uchwały nr 821/371/14 Zarządu Województwa Pomorskiego z dnia 29 lipca 2014 roku Program Wyrównywania Szans Osób Niepełnosprawnych Województwa Pomorskiego na lata 2014-2020. Załącznik do Uchwały Nr 82/167/V/2017 Zarządu Województwa Śląskiego z dnia 17 stycznia 2017 roku Wojewódzki program wyrównywania szans osób niepełnosprawnych oraz przeciwdziałania ich wykluczeniu społecznemu na lata 2017-2022. 
Załącznik do uchwały nr 2079/304/17 Zarządu Województwa Mazowieckiego z dnia 27 grudnia 2017 roku Wojewódzki Program Wyrównywania Szans Osób Niepełnosprawnych i Przeciwdziałania ich Wykluczeniu Społecznemu oraz Pomocy w Realizacji Zadań na Rzecz Zatrudniania Osób Niepetnosprawnych w Województwie Mazowieckim na lata 2017-2021.

\section{Literature}

Banaszek, B. (2009). Konstytucja Rzeczypospolitej Polskiej. Komentarz. Warsaw: Wydawnictwo C. H. Beck. Bogacz-Wojtanowska, E. (2013). Zdolności organizacyjne a współdziałania organizacji pozarządowych. Kraków: Instytut Spraw Publicznych Uniwersytetu Jagiellońskiego.

Bogacz-Wojtanowska, E. (2007). Modele wspótpracy lokalnych instytucji a rozwiązywanie problemów rynku pracy, Kraków: Wydawnictwo Uniwersytetu Jagiellońskiego.

Kaźmierczak, T. (ed.) (2008). Społeczność lokalna w działaniu: kapitał społeczny, lokalne governance. Warsaw: Instytut Spraw Publicznych.

Kożuch, B. (2015). Instrumentarium zarządzania publicznego. Warsaw: Diffin.

Kożuch, B. (2003). Zarządzanie publiczne w zarysie. Białystok: Fundacja Współczesne Zarządzanie.

Kożuch, B. (1997). Podstawy organizacji i zarzadzania. Białystok: Wydawnictwo Uniwersytetu w Białymstoku. Marks-Krzyszkowska, M. (2016). Zarządzanie publiczne - istota o wybrane koncepcje. Acta Uniwersitatis Lodziensis, Folia Sociologica, No. 56, pp. 37-51, http://dx.doi.org/10.18778/0208-600X.56.03

Marszałek-Kawa J. (2016). The Institutional Position and Functions of the Sejm of the Republic of Poland after the Accession to the European Union, Torun: Wydawnictwo Adam Marszałek.

Peter-Bombik, K. (2018). Participation of the citizens in the management of public affairs at the local level in Polish conditions. In Blašková M., Pangsy-Kania S., Drela K., Sokół A. (eds.), Contemporary issues and economic problems. Aaachen: Shaker Verlag.

Peter-Bombik, K. (2017), Socio-public cooperation in polish conditions. In Sokół A., Drab-Kurowska A., Budkiewicz-Guźlecka A. (eds.), Business entities in the face of contemporary economics, Bratislava: KARTPRINT.

Peter-Bombik, K., Szczudlińska-Kanoś, A. (2016). Partycypacyjny wymiar powiatowych strategii rozwiązywania problemów społecznych w Małopolsce. Zeszyty Naukowe Uniwersytetu HumanistycznoPrzyrodniczego w Siedlcach (seria Administracja i Zarządzanie), No. 108, pp. 87-96.

Peter-Bombik, K., Szczudlińska-Kanoś, A. (2015). Zarzadzanie partycypacyjne we wspólnotach lokalnych. Prace Naukowe Uniwersytetu Ekonomicznego we Wrocławiu, No. 391, pp. 83-91.

Skrzydło, W. (2000). Konstytucja Rzeczypospolitej Polskiej. Komentarz. Kraków: Kantor Wydawniczy Zakamycze.

Sześciło, D. (2014). Megatrendy w administrowaniu i zarządzaniu publicznym. In D. Sześciło (ed.) Administracja i zarządzanie publiczne. Nauka o wspótczesnej administracji. Warsaw: Wydawca Stowarzyszenie Absolwentów Wydziału Prawa i Administracji Uniwersytetu Warszawskiego.

Szumowski, W. (2014). Zarządzanie publiczne - próba systematyzacji koncepcji. Nauki o zarządzaniu, vol. 4, No. 21, pp. 86-98.

\section{Author}

\section{Katarzyna Wojewoda-Buraczyńska}

PhD, Department of Administration and Public Management, Faculty of Economic and Legal Sciences, Siedlce University of Natural Sciences and Humanities. Contact details: katarzyna.wojewodaburaczynska@uph.edu.pl 